\title{
Preparation and Sinterability of Forsterite Powders Derived from Heterogeneous Alkoxide Solution Containing Fine MgO Powders
}

\author{
Takeshi Shiono, Kazuyo Miyamoto, Yuka Sugishima \\ Yasunori Okamoto, Kunio Hayashi and Tomozo Nishikawa
} Department of Chemistry and Materials Technology, Kyoto Institute of Technology, Matsugasaki Sakyo-ku,
Kyoto 606 .

Received September 6, 1993

Forsterite $\left(\mathrm{Mg}_{2} \mathrm{SiO}_{4}\right)$ precursors were synthesized from heterogeneous alkoxide (tetraethyl orthosilicate: TEOS) solution including very fine $\mathrm{MgO}$ powders and homogeneous alkoxide solution with $\mathrm{Mg}\left(\mathrm{NO}_{3}\right)_{2} \cdot 6 \mathrm{H}_{2} \mathrm{O}$. The precursors from $\mathrm{MgO}$ were crystallized to forsterite with drastically exothermic reaction at about $840{ }^{\circ} \mathrm{C}$. The precursors from $\mathrm{Mg}\left(\mathrm{NO}_{3}\right)_{2} \cdot 6 \mathrm{H}_{2} \mathrm{O}$ consisted of $\mathrm{Mg}\left(\mathrm{NO}_{3}\right)_{2} \cdot 6 \mathrm{H}_{2} \mathrm{O}$ and little amorphous $\mathrm{SiO}_{2}$. The precursors began to crystallize to forsterite at a lower calcining tempcraturc than those from $\mathrm{MgO}$. However, $\mathrm{MgO}$ and enstatite $\left(\mathrm{MgSiO}_{3}\right)$ existed as a second phase in forsterite powders even at a calcining temperature more than $1000{ }^{\circ} \mathrm{C}$. The forsterite powders obtained from heterogeneous alkoxide solution with fine $\mathrm{MgO}$ had excellent sinterability. Sintering temperature of $1400{ }^{\circ} \mathrm{C}$ was found to be enough to make forsterite ceramics with theoretical density.

\section{Introduction}

Synthesis of ceramic precursors by solgel process from alkoxide solution has been extensively studied because of high-purity, homogeneity, low temperature processing and fabrication ${ }^{1-3)}$. These advantages are suitable for synthesizing high-purity submicroscopic powders as a starting material. In alkoxide method, first, homogeneous alkoxide solution should be usually prepared. Then the solution is hydrolyzed and polymerized to ceramic precursors. For mixed-oxide ceramics, however, it is very difficult to synthesize homogeneous precursor from mixed alkoxide solution because of difference in chemical reactivity of each alkoxide, such as hydrolysis and polymerization rate ${ }^{4)}$. In present study, forsterite ceramic precursor was tried to be synthesized from heterogeneous alkoxide solution including fine $\mathrm{MgO}$ powders, not from homogeneous alkoxide solution.

\section{Experimental procedure}

\subsection{Preparation of forsterite precursors}

Forsterite precursors were synthesized from tetraethyl orthosilicate, TEOS (98\% : Aldrich Chem. Co Inc.) and ultra-fine $\mathrm{MgO}$ powder (99.98\% : Ube Industries Ltd.). The mean particle size of $\mathrm{MgO}$ was $10 \mathrm{~nm}$. Preparation of the precursors is schematically shown in Fig.1. $\mathrm{MgO}$ powders were added to

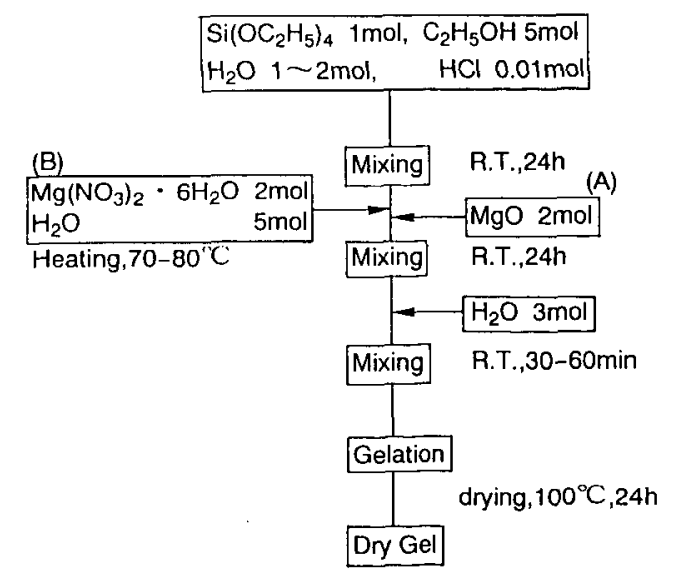

Fig.1 Schematic of preparing forsterite precursor. 
partially hydrolyzed TEOS solution and subsequent addition of distilled water promoted gelation of the solution. The obtained gels were dried at $100^{\circ} \mathrm{C}$ and calcined to forsterite at a temperature from $500^{\circ} \mathrm{C}$ to $1300^{\circ} \mathrm{C}$. In order to examine effects of a starting material on properties of precursors and calcined powders, magnesium nitrate solution was added to the alkoxide solution instead of $\mathrm{MgO}$ powders (Fig.1(B)).

\subsection{Characterization of precursors and calcined} powders

Thermal behaviors of precursors were examined with DTA and TGA. Crystalline phases of calcined powders and sintered bodies were identified by XRD analysis. The obtained forsterite powders were compacted to disk $(20 \times 5 \mathrm{~mm})$ at a pressure of $20 \mathrm{MPa}$ and isostatically pressed to $300 \mathrm{MPa}$. The disk was fired at a temperature from $1250{ }^{\circ} \mathrm{C}$ to $1550^{\circ} \mathrm{C}$. The microstructures of forsterite were observed with scanning electron microscopy (SEM). In order to estimate sinterability of each powder, density of sintered bodies were measured as a function of sintering temperature.

\section{Results and discussion}

Heterogeneous alkoxide solution with $\mathrm{MgO}$ powders was creamy white and stable. Subsequent addition of $\mathrm{H}_{2} \mathrm{O}$ promoted gelation of the solution. The gelation with a small amount of $\mathrm{H}_{2} \mathrm{O}\left(\mathrm{H}_{2} \mathrm{O} / \mathrm{Si}\left(\mathrm{OC}_{2} \mathrm{H}_{5}\right)_{4}=4\right)$ was finished in about $20 \mathrm{~min}$ and the gelation time decreased with increasing a ratio of $\mathrm{H}_{2} \mathrm{O} / \mathrm{Si}\left(\mathrm{OC}_{2} \mathrm{H}_{5}\right)_{4}$. For $\mathrm{H}_{2} \mathrm{O} / \mathrm{Si}\left(\mathrm{OC}_{2} \mathrm{H}_{5}\right)_{4} \geq 7$, for example, the gelation was finished in 10 min during addition of $\mathrm{H}_{2} \mathrm{O}$. The dried precursors with a small amount of $\mathrm{H}_{2} \mathrm{O}$ were identified as a mixture of amorphous $\mathrm{SiO}_{2}$ and $\mathrm{MgO}$. On the other hand, alkoxide solution prepared with $\mathrm{Mg}\left(\mathrm{NO}_{3}\right)_{2} \cdot 6 \mathrm{H}_{2} \mathrm{O}$ was homogeneous and uniformly transparent. During drying process, however, the solution became translucent to gel because of precipitation of $\mathrm{Mg}\left(\mathrm{NO}_{3}\right)_{2}$.

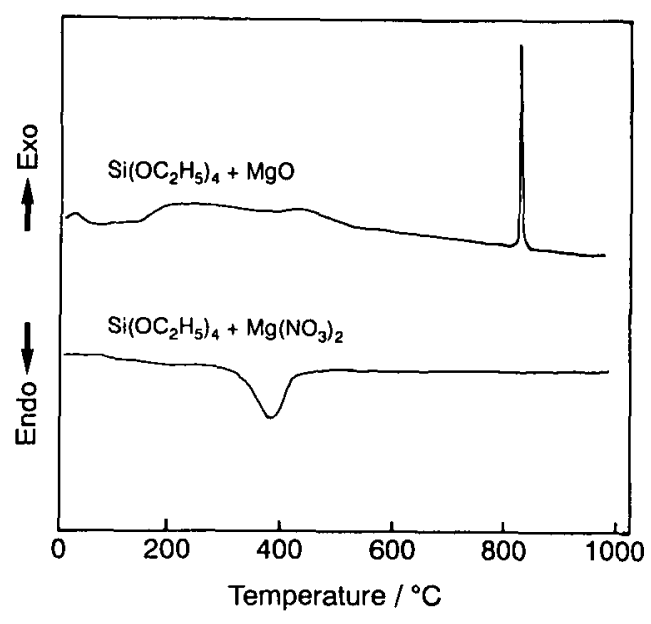

Fig.2 DTA curves of forsterite precursor prepared from $\mathrm{MgO}$ and magnesium nitrate.

$6 \mathrm{H}_{2} \mathrm{O}$. The nitrate in precursors was identified by XRD analysis.

Fig. 2 shows thermal behaviors of forsterite precursors prepared with $\mathrm{MgO}$ powders and magnesium nitrate. For the precursor prepared with $\mathrm{MgO}$ powders, drastically exothermic reaction occurred around $840^{\circ} \mathrm{C}$. Weight of the precursor was gradually decreased with temperature and no remarkable change was recognized at $840{ }^{\circ} \mathrm{C}$, For the precursor with $\mathrm{Mg}\left(\mathrm{NO}_{3}\right)_{2} \cdot 6 \mathrm{H}_{2} \mathrm{O}$, on the other hand, only endothermic reaction occurred gently at about $380^{\circ} \mathrm{C}$ and weight of the precursor decreased, accompanied with the endothermic reaction. This change at $380^{\circ} \mathrm{C}$ was found to be due to the decomposition of nitric group because of the odor and color of the decomposed gas. In order to examine the formation of forsterite phase, XRD analysis was carried out. The patterns of each precursor calcined at various temperatures are given in Fig. 3 and 4. In case of the precursor prépared with $\mathrm{MgO}$ powders by using a small amount of $\mathrm{H}_{2} \mathrm{O}\left(\mathrm{H}_{2} \mathrm{O} / \mathrm{Si}\left(\mathrm{OC}_{2} \mathrm{H}_{5}\right)_{4}=4\right)$, no forsterite phase was observed below the exothermic reaction temperature shown in Fig.2, but the precursor all crystallized to forsterite beyond the temperature. Consequently, the exothermic peak was judged to be caused by 


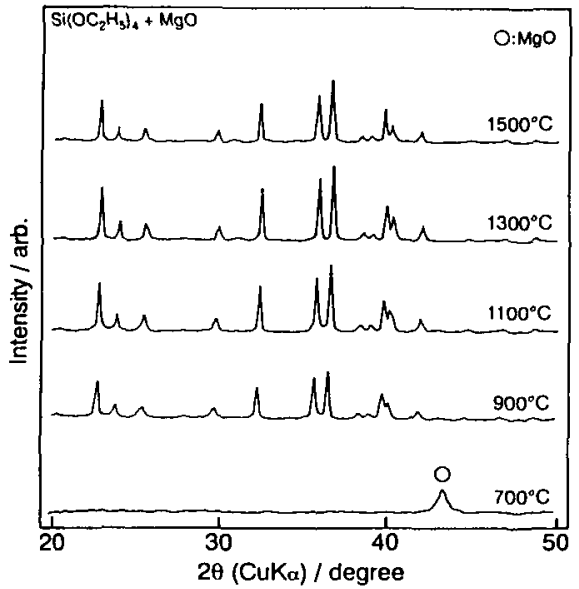

Fig.3 XRD patterns for forsterite powders prepared from TEOS and $\mathrm{MgO}$ after calcining at various temperatures.

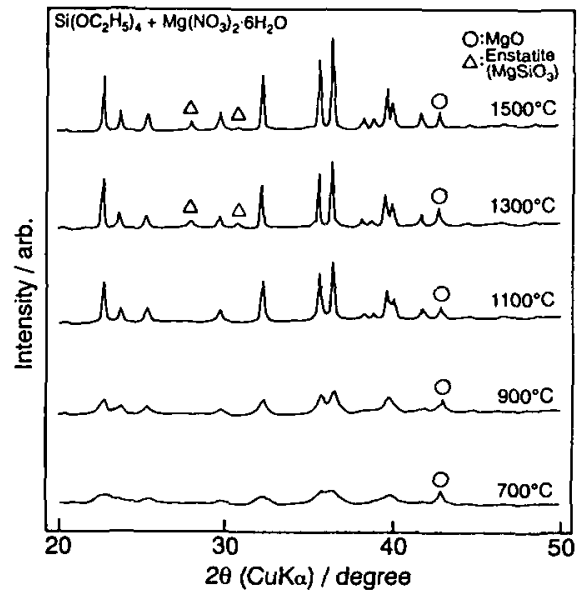

Fig.4 XRD patterns for forsterite powders prepared from TEOS and $\mathrm{Mg}\left(\mathrm{NO}_{3}\right)_{2} \cdot 6 \mathrm{H}_{2} \mathrm{O}$ after calcining at various temperatures.

crystallization to forsterite from a mixture of $\mathrm{MgO}$ and amorphous $\mathrm{SiO}_{2}$. The formation of forsterite was remarkably promoted like selfcombustion reaction by heat of the reaction. And the heat was so large to enhance the crystallinity of forsterite powders. As for the precursor prepared with $\mathrm{Mg}\left(\mathrm{NO}_{3}\right)_{2} \cdot 6 \mathrm{H}_{2} \mathrm{O}$, forsterite phase began to form at a lower temperature than that of the precursor with $\mathrm{MgO}$ powders. Forsterite phase was recognized to form even at a calcining temperature of $700^{\circ} \mathrm{C}$.
In case of utilizing magnesium nitrate for preparation of forsterite precursors, however, monolithic forsterite powders could not be obtained regardless of a calcining temperature. For example, $\mathrm{MgO}$ existed as a second phase at low calcining temperatures, and $\mathrm{MgO}$ and enstatite $\left(\mathrm{MgSiO}_{3}\right)$ at high temperatures. As mentioned above, the precursors from $\mathrm{Mg}\left(\mathrm{NO}_{3}\right)_{2}$ consisted of $\mathrm{Mg}\left(\mathrm{NO}_{3}\right)_{2}$ and a little amorphous $\mathrm{SiO}_{2}$ macroscopically, according to XRD analysis. Takeuchi ${ }^{5)}$ investigated glassforming region of $\mathrm{SiO}_{2}-\mathrm{MgO}$ system from TEOS and $\mathrm{Mg}\left(\mathrm{NO}_{3}\right)_{2} \cdot 6 \mathrm{H}_{2} \mathrm{O}$ by sol-gel method. For a low content of $\mathrm{Mg}\left(\mathrm{NO}_{3}\right)_{2}\left(\mathrm{O}_{-}\right.$ $15 \mathrm{~mol} \%$ as $\mathrm{MgO}$ concentration), no $\mathrm{Mg}\left(\mathrm{NO}_{3}\right)_{2} \cdot 6 \mathrm{H}_{2} \mathrm{O}$ was detected in dried gels by XRD analysis and the gels formed as amorphous. For a content more than $20 \mathrm{~mol} \%$ of $\mathrm{MgO}$, however, more $\mathrm{Mg}\left(\mathrm{NO}_{3}\right)_{2} \cdot 6 \mathrm{H}_{2} \mathrm{O}$ appeared in the dried gels with increasing the content. Concentration of $\mathrm{MgO}$ in forsterite is $66 \mathrm{~mol} \%$ and only $\mathrm{Mg}\left(\mathrm{NO}_{3}\right)_{2} \cdot 6 \mathrm{H}_{2} \mathrm{O}$ was detected in this concentration. It is inferred that the gels have a wide distribution in size of precipitated $\mathrm{Mg}\left(\mathrm{NO}_{3}\right)_{2} \cdot 6 \mathrm{H}_{2} \mathrm{O}$ and that $\mathrm{Mg}\left(\mathrm{NO}_{3}\right)_{2} \cdot 6 \mathrm{H}_{2} \mathrm{O}$ with small size contributes to formation of forsterite at lower temperatures and that some of large $\mathrm{Mg}\left(\mathrm{NO}_{3}\right)_{2} \cdot 6 \mathrm{H}_{2} \mathrm{O}$ are left as $\mathrm{MgO}$ powders at higher temperatures.

Powders calcined at $900^{\circ} \mathrm{C}$ were pressed to a disk with $20 \mathrm{~mm}$ in diameter and $5 \mathrm{~mm}$ in thickness and isostatically pressed at a pressure of $300 \mathrm{MPa}$. The obtained compacts were sintered at various temperatures to examine their sinterability. Fig. 5 shows relative density of sintered forsterite body as a function of sintering temperature. For powders from $\mathrm{MgO}$, sintering at $1400{ }^{\circ} \mathrm{C}$ was enough to obtain fully dense forsterite. Higher sintering temperatures made the density only a little lower. Such degradation is inferred to result from remarkable grain growth. Photo. 1 (A) and (B) show typical microstructures of forsterite ceramics sintered at $1400^{\circ} \mathrm{C}$ and $1550^{\circ} \mathrm{C}$, respectively. The mean grain size of forsterite sintered at $1400{ }^{\circ} \mathrm{C}$ is $2.7 \mu \mathrm{m}$ and grains 


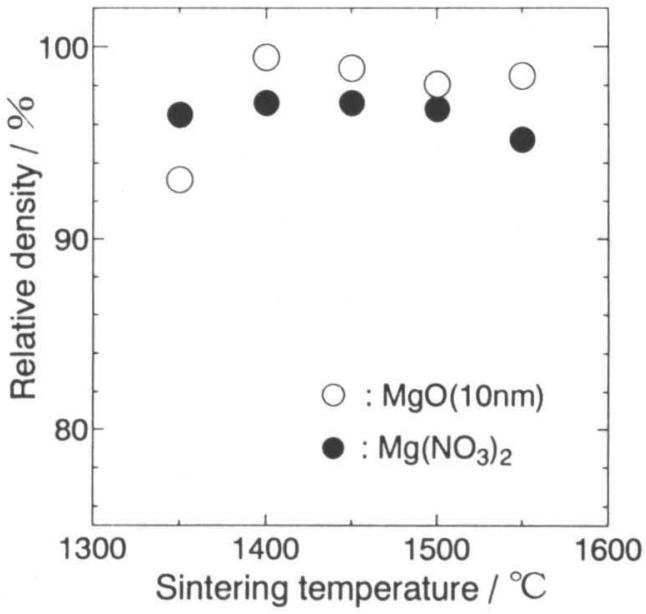

Fig.5 Effect of sintering temperature on relative density of polycrystalline forsterite.
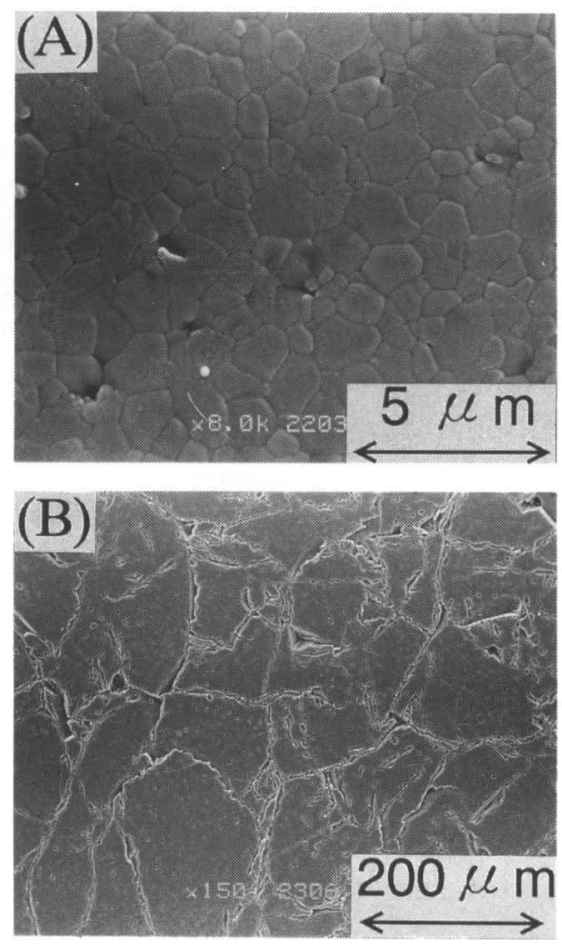

Photo 1 Typical microstructures of forsterite sintered at $1400^{\circ} \mathrm{C}(\mathrm{A})$ and $1550^{\circ} \mathrm{C}(\mathrm{B})$.

were relatively uniform. Large cracks are observed on the ceramics sintered at higher temperatures. These cracks are guessed to be caused by remarkable grain growth. For powders from $\mathrm{Mg}\left(\mathrm{NO}_{3}\right)_{2} \cdot 6 \mathrm{H}_{2} \mathrm{O}$, denser forsterite ceramics were produced at lower sintering temperatures but higher sintering temperatures did not enhance the density. $\mathrm{MgO}$ existed in sintered bodies and was inferred to result from $\mathrm{MgO}$ in calcined forsterite powders. In order to improve forsterite powders from $\mathrm{Mg}\left(\mathrm{NO}_{3}\right)_{2}$. $6 \mathrm{H}_{2} \mathrm{O}$, particle size of precipitated nitrate was expected to be much smaller and uniform. The microstructures of forsterite from $\mathrm{Mg}\left(\mathrm{NO}_{3}\right)_{2} \cdot 6 \mathrm{H}_{2} \mathrm{O}$ were almost resemble to those from $\mathrm{MgO}$ powders.

\section{Summary}

Forsterite $\left(\mathrm{Mg}_{2} \mathrm{SiO}_{4}\right)$ precursors were synthesized from heterogeneous alkoxide solution including very fine $\mathrm{MgO}$ powders and homogeneous alkoxide solution with $\mathrm{Mg}\left(\mathrm{NO}_{3}\right)_{2} \cdot 6 \mathrm{H}_{2} \mathrm{O}$. The precursors from $\mathrm{MgO}$ were crystallized to forsterite with drastically exothermic reaction at about $840{ }^{\circ} \mathrm{C}$. The precursors from $\mathrm{Mg}\left(\mathrm{NO}_{3}\right)_{2} \cdot 6 \mathrm{H}_{2} \mathrm{O}$ consisted of $\mathrm{Mg}\left(\mathrm{NO}_{3}\right)_{2} \cdot 6 \mathrm{H}_{2} \mathrm{O}$ and a little amorphous $\mathrm{SiO}_{2}$. The precursors began to crystallized to forsterite at a lower calcining temperature than those from $\mathrm{MgO}$. However, $\mathrm{MgO}$ and enstatite $\left(\mathrm{MgSiO}_{3}\right)$ as second phase existed in forsterite powders even at a calcining temperature more than $1000{ }^{\circ} \mathrm{C}$. The forsterite powders obtained heterogeneous alkoxide solution with $\mathrm{MgO}$ showed excellent sinterability.

\section{Reference}

1) F.F.Lange : p.p.611-26 in "Chemical Processing of Advanced Materials ", edited by L.L.Hench and J.K.West (John Wiley \& Sons, Inc., 1992).

2) S.Hirano, T.Hayashi, K.Nosaki and K.Kato : J.Am.Ceram.Soc., 72 (1989) 707.

3) K.D.Budd, S.K.Dey and D.A.Payne : Proc. Br. Ceram. Soc., 36 (1985) 107.

4) M.Sugiura and O.Kamigaito : YogyoKyokai-Shi, 92 (1984) 605.

5) A.Takeuchi:Graduation Thesis, Department of Chemistry and Materials Technology, Kyoto Institute of Technology. 